\title{
Knowledge Management Practices in Technical Educational Institutions using ICT tools of Rayalaseema Region in Andhra Pradesh
}

\author{
P. Haripriya, N.S. Chakravarthy, Y.V.Siva Reddy
}

\begin{abstract}
Information and Communication Technology (ICT) is a facilitator of quality education in this technology driven world. ICT has the ability to deliver information and make education accessible to the mass. Knowledge management is another crucial application of ICT where the technology is used to create, obtain, distribute, apprehend and use information for knowledge advancement in students and employees. The current study analyses the extent of application of ICT enabled tools in knowledge management. The study concentrated the Rayalaseema region of Andhra Pradesh. Data regarding use of ICT tools with respect to knowledge management was collected from faculty members and administrative and management officials of technical educational institutions of entire Rayalaseema region. The respondents were selected on the purposive basis from each of the 4 districts. Thus, the total number of respondents for the study was 173. Most of the research respondents were in favour of use of ICT tools for knowledge management in students of technical educational institutions.
\end{abstract}

Keywords - Information and Communication Technology, ICT, Knowledge Management, KM, Technical education

\section{INTRODUCTION}

Human race of 21 st century live amidst the unprecedented transformation of technological landscape with new technologies replacing the old ones each day. The survival and growth of human race are increasingly dependent upon the learning capabilities or the education processes. Advancement of information technology has made education complex and yet accessible at the same time. Incorporation of Information and Communication Technologies (ICTs) in education programs of India started in 1984-85 with computer literacy studies in schools (CLASS) project (Maryam, 2013). Today, ICT enabled education is not only a learning and teaching tool, rather a vehicle for development, women empowerment and a cultural tool kit. ICTs facilitate teaching and learning at any place and at any time. ICT has favourable impact on quality of education, access of education, learning outcomes and management of overall education processes (Sarkar, 2012). Apart from education, ICT is an important tool for socio economic growth and development. In rural areas, ICT tools are used for better agricultural practices, in healthcare sectors, and in businesses. Improvement in accountability

Revised Manuscript Received on July 10, 2019.

P. Haripriya, Research Scholar, PP. MAN. 0088 Management

Rayalaseema University, Kurnool, Andhra Pradesh, India.

Dr. N.S. Chakravarthy, Associate Professor in Management,

Bhavans Vivekananda College, Sainikpuri, Secunderabad,Telangana India.

Dr.Y.V.Siva Reddy, Professor in Electrical Engineering, GPREC,

Kurnool, Andhra Pradesh, India. and transparency, interactive structure for financial dealings, framework for social, legal, supervisory and regulatory activities, multi-channel operations, and mobile banking are some of the advantages of information and communication technologies. Growth of information technology and its adaptation leads to digitisation of the market. In rural areas digitisation transforms to sustained development through emergence of new markets. ICT also brings innovation to the market and thus investments increases which in turn propel job creation (Agrawal, 2016).

Facilitation of knowledge management is another major application of ICT. Traditionally knowledge management has been associated with business organisations where the competitive advantage is depended upon the availability of knowledge and its internal flow. Creation, obtainment, distribution, apprehension and use of knowledge are all part of knowledge management processes. It is one of the vital ingredients for success of organisations. Knowledge management helps in strengthening competency, speeding the innovation, increasing organisational commitment and in decision making processes of business entities. This business development technique can also be used in educational institutions where the learning processes of students can be accelerated and make them competent for the job market. ICT is an efficient tool for improving knowledge and learnings of students. It can provide better access to information and increase the quality of education in low cost (Gyaase, Anane\&Armah, 2015). In a developing country like India, where majority of population is young and cost is always a constraint, ICT can be an effective apparatus for educational institutions. The present study thus analyses the application of IOT in knowledge management processes of technical institutions with special reference to Rayalaseema region in Andhra Pradesh.

\section{Objectives}

The primary aim of the research is to evaluate the use of information and communication technological tools in knowledge management practices of technical educational institutions of Rayalaseema region in Andhra Pradesh.

The objectives are:

- To analyse the use of ICT tools for knowledge management in engineering colleges of Rayalaseema region in Andhra Pradesh

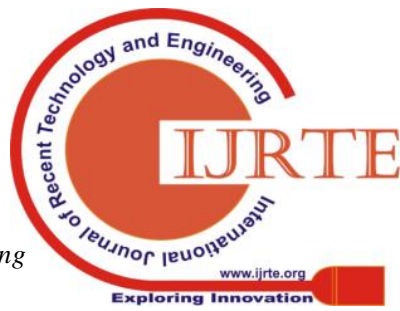




\section{KNOWLEDGE MANAGEMENT PRACTICES IN TECHNICAL EDUCATIONAL INSTITUTIONS USING ICT TOOLS OF RAYALASEEMA REGION IN ANDHRA PRADESH}

- To assess the knowledge management practices followed by technical educational institutions in Rayalaseema region of Andhra Pradesh

- To analyse the key areas in the technical educational institutions where knowledge management practices are being followed

- To examine how ICT enabled knowledge management practices lead to strengthen the human resources

- To assess the shortcomings of present ICT enabled knowledge management practices of technical educational institutions in Rayalaseema region of Andhra Pradesh

- To offer suitable suggestions for further improvement of ICT enabled knowledge management practices

\section{LITERATURE REVIEW}

\section{Significance of Knowledge management in institutions of higher learning}

Nawaz and Gomes (2014) reviewed the state of knowledge management in higher education institutions in their study. The paper pointed two strategies of knowledge, which are strategic knowledge and innovations knowledge. Strategic knowledge defines basic knowledge as explicit and tacit, on the other hand innovative knowledge considers strategic knowledge as the basic knowledge. Both the strategies work towards knowledge management of students in higher educational institutions. The primary motivation behind higher educational knowledge management is to produce knowledge workers who can exhibit better cognitive, analytic and managerial skills. These people can share their knowledge in or out of University and collaborate for organisational development.

Laal (2011) in his study on knowledge management in higher education postulated that knowledge management is a systematic activity which requires a standardised framework. The processes as described by the researcher for better management of knowledge are:

- Development of fundamental processes and competence

- Figuring the missing elements

- Benchmarking the activities

- Dissemination of internal knowledge

- Developing supportive learning environment

- Working on studied knowledge gaps

- Inspection of assumptions

- Explicit description of Implicit information

- Learning from failures

Pinto (2014) proposed a framework for improvement in knowledge management practices of higher education institutions. The researcher presented the practices of knowledge management which is represented in table 1.

Table 1: Knowledge management practices

\begin{tabular}{|l|l|l|}
\hline Sl. No. & Knowledge management practices & Description \\
\hline 1 & Communities of practice & $\begin{array}{l}\text { This is formed by learners. The interest of learners are similar in nature and } \\
\text { they may also belong to same organisation, activity or group }\end{array}$ \\
\hline 2 & Best Practices & $\begin{array}{l}\text { This step includes identification and assimilation of practices that are both } \\
\text { efficient and productive. It is also part of the benchmarking process }\end{array}$ \\
\hline 3 & Learned lessons & $\begin{array}{l}\text { The gathered and learned lesson has to be validated so as to determine the } \\
\text { learning progress }\end{array}$ \\
\hline 5 & Focial interaction & $\begin{array}{l}\text { This consists of teaching or learning session with study materials. Workshops, } \\
\text { seminars and conferences are some of the examples }\end{array}$ \\
\hline 6 & Competence maps & $\begin{array}{l}\text { Collaboration with known or unknown people over internet based platforms for } \\
\text { information and learning }\end{array}$ \\
\hline 7 & Corporate Education & $\begin{array}{l}\text { It is the representative format of skills, knowledge and competence of human } \\
\text { capital of any organisation }\end{array}$ \\
\hline
\end{tabular}

Source: Pinto (2014)

Strategy of IT in enhancing knowledge management in engineering colleges

Madhar (2010) studied the knowledge management practices of applied science colleges and postulated that advancement of technology has bought new changes in the way knowledge management has been originally carried out. Knowledge managers are the important facilitators of knowledge management practices. The roles of knowledge manager are to innovate novel knowledge, disseminate gathered knowledge among the fellow beings and apply the acquired knowledge 
wherever necessary. The study described three knowledge management initiatives. Those are: external structure initiative, internal structure initiative, and competence initiative. Proper adoption of these initiatives in managing the knowledge management activities will result in optimal management of human capital in educational institutions.

\section{Research Gap}

The review of literatures disclosed the gap in researches relating to ICT for knowledge management in technical institutions in India. There is scarcity of studies on the topic and pertaining to Rayalaseema region none exists. The relevance and importance of ICT for technical education in India is indisputable. However, in the absence of quality research the state of ICT enabled knowledge management practices and its associated characteristics such as impacts and limitations are unknown. This research can bridge that gap and provide suggestions for improvement of ICT enabled knowledge management practices.

\section{MATERIALS AND METHODS}

Method: The research is applied research and follows descriptive research methodology. Deductive research approach is followed in this study for data collection which is quantitative in nature.

Population and Sampling: The population of the study is faculty members and administrative and management officials of technical educational institutions of entire Rayalaseema region in Andhra Pradesh. For selection of representative sample, stratification was carried out on the basis of administrative areas. The Rayalaseema region is constituted of 4 districts. Multistage sampling technique was adopted, i.e., stratify for selecting the respondents of the study. At the first stage all four districts were selected. In the final stage, from each of the districts, a modest sample was selected on the purposive basis and the total number of respondents for the study was 173 . Table 2 represents the distribution of sample respondents across the 4 districts.

Table 2: Distribution of Sample Respondents in revenue divisions

\begin{tabular}{|l|l|l|}
\hline Districts & Number of Respondents & Percentage \\
\hline Kurnool & 58 & 33.5 \\
\hline Kadapa & 34 & 19.6 \\
\hline Anantapur & 37 & 21.3 \\
\hline Chittoor & 44 & 25.6 \\
\hline Total & $\mathbf{1 7 3}$ & $\mathbf{1 0 0}$ \\
\hline
\end{tabular}

Source: Field Survey

Instrument: A set of close ended questionnaire was prepared for primary data collection through survey method. For secondary data, information was sought from concerned educational institutions.

Data Analysis: The collected data was analysed through statistical tests such as mean scores, frequencies, percentages, significance, Chi Square analysis and ANOVA using SPSS software.

Ethical consideration: Prior permissions were taken from concerned authorities for data collection. The anonymity and confidentiality of the respondents are maintained. The researcher declares that there is no conflict of interest.

\section{RESULTS}

Table 3: Engineering branches in Institutions

\begin{tabular}{|ll|l|l|l|l|}
\hline & Frequency & Percent & Valid Percent & Cumulative Percent \\
\hline Valid & Applied Electronics & 1 & .6 & .6 & .6 \\
& Civil engineering & 4 & 2.3 & 2.3 & 2.9 \\
& Computer Science & 86 & 49.7 & 49.7 & 52.6 \\
Electrical Engineering & 34 & 19.7 & 19.7 & 72.3 \\
Electronics and Telecommunication & 35 & 20.2 & 20.2 & 92.5 \\
Mechanical Engineering & 13 & 7.5 & 7.5 & 100.0 \\
Total & 173 & 100.0 & 100.0 & \\
\hline
\end{tabular}

From the tablewe conclude that out of 173 respondent, $49.7 \%$ have computer science, $20.2 \%$ have electronic and telecommunication of branches of engineering course. It is also represented in bar graph.

Table 4: Primary sources of teaching materials in institutions

\begin{tabular}{|ll|l|l|l|l|}
\hline & & Frequency & Percent & Valid Percent & Cumulative Percent \\
\hline Valid & Internet & 8 & 4.6 & 4.6 & 4.6 \\
& Notes facilitated by the institution & 5 & 2.9 & 2.9 & 7.5
\end{tabular}


KNOWLEDGE MANAGEMENT PRACTICES IN TECHNICAL EDUCATIONAL INSTITUTIONS USING ICT TOOLS OF RAYALASEEMA REGION IN ANDHRA PRADESH

\begin{tabular}{|l|l|l|l|l|}
\hline Notes prepared by faculties & 58 & 33.5 & 33.5 & 41.0 \\
Others & 4 & 2.3 & 2.3 & 43.4 \\
Text Books & 98 & 56.6 & 56.6 & 100.0 \\
Total & 173 & 100.0 & 100.0 & \\
\hline
\end{tabular}

From table we conclude that out of $173,56.6 \%$ used textbooks and $33.5 \%$ used notes prepared by faculties as the primary sources of teaching materials in institutes.

Table 5: Active Knowledge management system

\begin{tabular}{|ll|r|r|r|r|}
\hline & \multicolumn{2}{|c|}{ Frequency } & Percent & \multicolumn{1}{c|}{ Valid Percent } & Cumulative Percent \\
\hline Valid & No & 26 & 15.0 & 15.0 & 15.0 \\
& Not sure & 28 & 16.2 & 16.2 & 31.2 \\
& Yes & 119 & 68.8 & 68.8 & 100.0 \\
& Total & 173 & 100.0 & 100.0 & \\
\hline
\end{tabular}

Table 5 represents the existence of active knowledge management system in educational institutions. Around $68.8 \%$ of the responded acknowledged the presence of active knowledge management system in their institutions.

Table 6:Culture of Knowledge management

\begin{tabular}{|c|c|c|c|}
\hline \multicolumn{4}{|c|}{ Descriptive Statistics } \\
\hline & Mean & Std. Deviation & $\mathrm{N}$ \\
\hline The teaching culture of our organisation is flexible & 4.04 & 0.92 & 165 \\
\hline $\begin{array}{l}\text { Students do not have the obligation towards mandatory } \\
\text { attendance in our institution }\end{array}$ & 3.85 & 1.151 & 165 \\
\hline $\begin{array}{l}\text { Students are expected to learn their lessons, in whichever means } \\
\text { they find suitable }\end{array}$ & 4.12 & 0.868 & 165 \\
\hline Our institution promotes creativity among faculties and students & 3.87 & 1.122 & 165 \\
\hline $\begin{array}{l}\text { Management seeks industry-wide best practices of knowledge } \\
\text { management }\end{array}$ & 3.79 & 1.051 & 165 \\
\hline $\begin{array}{l}\text { Management implements knowledge management related best } \\
\text { practices in the academic curriculum }\end{array}$ & 3.87 & 1.043 & 165 \\
\hline $\begin{array}{l}\text { Knowledge management practices are encouraged among the } \\
\text { faculties and students }\end{array}$ & 4.02 & 0.991 & 165 \\
\hline $\begin{array}{l}\text { Knowledge management practices are recorded positively in the } \\
\text { performance appraisal of faculty members }\end{array}$ & 3.85 & 1.016 & 165 \\
\hline $\begin{array}{l}\text { Individual faculty members are recognised and facilitated for } \\
\text { knowledge management related activities }\end{array}$ & 3.91 & 0.993 & 165 \\
\hline $\begin{array}{l}\text { The feedback mechanism is present to evaluate the knowledge } \\
\text { management related activities of people involved }\end{array}$ & 4.09 & 0.936 & 165 \\
\hline
\end{tabular}

Table 6 describes the descriptive statistics of culture of knowledge management in the selected educational institutions. The statement "Students are expected to learn their lessons, in whichever means they find suitable" has the highest mean score (Mean=4.12) which denotes most of the respondents agreed to the statement. Statements "Knowledge management practices are recorded positively in the performance appraisal of faculty members" and "Students do not have the obligation towards mandatory attendance in our institution" have the least mean score $($ Mean=3.85) as majority of the respondents opposed the both statements. 
Table 7:ICT enabled knowledge management approaches and practices.

\begin{tabular}{|c|c|c|c|}
\hline \multicolumn{4}{|c|}{ Descriptive Statistics } \\
\hline & Mean & $\begin{array}{c}\text { Std. } \\
\text { Deviation }\end{array}$ & $\mathrm{N}$ \\
\hline $\begin{array}{l}\text { Areas, where knowledge } \\
\text { management is required, are } \\
\text { identified in each academic } \\
\text { year }\end{array}$ & 4.08 & 0.866 & 173 \\
\hline $\begin{array}{l}\text { Identification of knowledge } \\
\text { resources required for } \\
\text { knowledge management is } \\
\text { carried out by a dedicated } \\
\text { committee of experts }\end{array}$ & 3.9 & 0.944 & 173 \\
\hline $\begin{array}{l}\text { Acquisition and creation of } \\
\text { knowledge related sources } \\
\text { are very important processes } \\
\text { for our organisation }\end{array}$ & 4.08 & 0.883 & 173 \\
\hline $\begin{array}{l}\text { Creation of knowledge } \\
\text { related environment is } \\
\text { emphasised by the } \\
\text { management }\end{array}$ & 3.95 & 0.981 & 173 \\
\hline $\begin{array}{l}\text { Storage of knowledge is } \\
\text { carried out by the delegated } \\
\text { workforce }\end{array}$ & 3.86 & 0.973 & 173 \\
\hline $\begin{array}{l}\text { Information and } \\
\text { Communication } \\
\text { technological tools are used } \\
\text { in knowledge management } \\
\text { processes }\end{array}$ & 3.91 & 1.016 & 173 \\
\hline $\begin{array}{l}\text { IT security systems such as } \\
\text { virus and firewall protection } \\
\text { are in place for ICT tools } \\
\text { used in knowledge } \\
\text { management }\end{array}$ & 3.94 & 0.969 & 173 \\
\hline $\begin{array}{l}\text { Existing sources of } \\
\text { knowledge are backed up } \\
\text { using ICT tools }\end{array}$ & 3.92 & 0.952 & 173 \\
\hline $\begin{array}{l}\text { Existing Knowledge } \\
\text { Management systems are } \\
\text { periodically revised to } \\
\text { incorporate new } \\
\text { developments in ICT tools }\end{array}$ & 3.94 & 0.941 & 173 \\
\hline $\begin{array}{l}\text { Adequate infrastructure is } \\
\text { there to facilitate knowledge } \\
\text { management activities }\end{array}$ & 3.95 & 0.936 & 173 \\
\hline $\begin{array}{l}\text { Requisite technological } \\
\text { equipments are available for } \\
\text { knowledge management } \\
\text { activities }\end{array}$ & 3.93 & 0.956 & 173 \\
\hline
\end{tabular}

Training programs for faculties are conducted to encourage and train them towards knowledge management

Appropriate funding is allocated towards ICT enabled knowledge management equipments purchase and maintenance

The management of the institution place sufficient importance on knowledge management related activities and sessions

The interfaces of ICT enabled knowledge management tools are easy to use

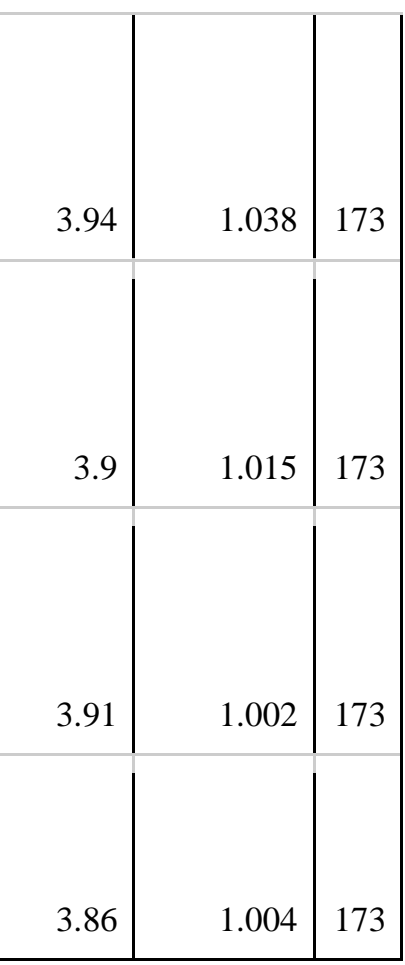

Table 7 represents the descriptive statistics for ICT enabled knowledge management approaches and practices followed by selected technical educational institutions. Majority of respondents agreed that "Areas, where knowledge management is required, are identified in each academic year" and "Acquisition and creation of knowledge related sources are very important processes for our organisation" as both the statements have highest mean score $(M e a n=4.08)$. The study participants had least agreement with the statements "The interfaces of ICT enabled knowledge management tools are easy to use" and "Storage of knowledge is carried out by the delegated workforce" as these two statements have lowest mean score $($ Mean $=3.86)$.

Table 8: Culture of knowledge sharing using ICT

\begin{tabular}{|c|c|c|c|}
\hline \multicolumn{4}{|c|}{ Descriptive Statistics } \\
\hline & Mean & $\begin{array}{c}\text { Std. } \\
\text { Deviation }\end{array}$ & $\mathrm{N}$ \\
\hline $\begin{array}{l}\text { The institution has an in- } \\
\text { house discussion forum for } \\
\text { knowledge sharing }\end{array}$ & 3.91 & 1.005 & 173 \\
\hline $\begin{array}{l}\text { The institution uses various } \\
\text { paid and unpaid discussion } \\
\text { and file sharing platforms to } \\
\text { facilitate knowledge sharing }\end{array}$ & 3.89 & 0.924 & 173 \\
\hline $\begin{array}{l}\text { Both students and faculty } \\
\text { members are active members } \\
\text { of discussion or file sharing } \\
\text { platforms }\end{array}$ & 3.97 & 0.991 & 173 \\
\hline
\end{tabular}

Published By 
KNOWLEDGE MANAGEMENT PRACTICES IN TECHNICAL EDUCATIONAL INSTITUTIONS USING ICT TOOLS OF RAYALASEEMA REGION IN ANDHRA PRADESH

\begin{tabular}{|l|r|r|r|}
\hline $\begin{array}{l}\text { The instituti006Fn has an } \\
\text { interactive knowledge } \\
\text { management intranet site }\end{array}$ & 3.87 & 1.026 & 173 \\
\hline $\begin{array}{l}\text { Meetings and workshops are } \\
\text { organised to share knowledge } \\
\text { among students and faculty } \\
\text { members }\end{array}$ & 4.01 & 0.97 & 173 \\
\hline $\begin{array}{l}\text { Majority of students actively } \\
\text { participate in educational } \\
\text { discussion forums }\end{array}$ & & & \\
\hline $\begin{array}{l}\text { Speakers and experts from } \\
\text { various fields are invited by } \\
\text { the institution to have } \\
\text { sessions with students }\end{array}$ & 4.08 & 0.934 & 173 \\
\hline $\begin{array}{l}\text { There are specific time slots } \\
\text { in the academic schedule } \\
\text { where the students have } \\
\text { discussion or learning } \\
\text { sessions over the internet }\end{array}$ & 3.97 & 1.017 & 173 \\
\hline $\begin{array}{l}\text { Periodic industry and } \\
\text { institution collaborated } \\
\text { sessions and seminars are } \\
\text { organised for various } \\
\text { departments }\end{array}$ & 1.082 & 173 \\
\hline
\end{tabular}

Table 8 describes the descriptive statistics for culture of knowledge sharing in the selected educational institutions. Respondents agreed that "Speakers and experts from various fields are invited by the institution to have sessions with students" as this statement has the highest mean score (Mean=4.08). Majority of the respondents were least agreeable towards the statement "There are specific time slots in the academic schedule where the students have discussion or learning sessions over the internet" and hence the statement got lowest mean score $($ Mean $=3.80)$.

Table 9:Faculty interaction and perception towards ICT

\begin{tabular}{|c|c|c|c|}
\hline \multicolumn{4}{|c|}{ Descriptive Statistics } \\
\hline & Mean & $\begin{array}{c}\text { Std. } \\
\text { Deviation }\end{array}$ & $\mathrm{N}$ \\
\hline $\begin{array}{l}\text { Knowledge sharing is a } \\
\text { strength to the organisation } \\
\text { and to the country }\end{array}$ & 4.32 & 0.792 & 173 \\
\hline $\begin{array}{l}\text { Interpersonal relationship } \\
\text { among the faculties } \\
\text { strengthens due to } \\
\text { knowledge sharing }\end{array}$ & 4.18 & 0.854 & 173 \\
\hline $\begin{array}{l}\text { Learning abilities of faculties } \\
\text { also increase due to } \\
\text { knowledge management }\end{array}$ & 4.22 & 0.841 & 173 \\
\hline $\begin{array}{l}\text { Sharing of knowledge among } \\
\text { faculty members enhances } \\
\text { overall skills of faculties } \\
\text { involved in the discussions }\end{array}$ & 4.21 & 0.802 & 173 \\
\hline
\end{tabular}

\begin{tabular}{|l|r|r|r|}
\hline $\begin{array}{l}\text { Most of the faculties are } \\
\text { adequately trained for ICT } \\
\text { enabled knowledge } \\
\text { management }\end{array}$ & 3.91 & 0.929 & 173 \\
\hline $\begin{array}{l}\text { Regular faculty development } \\
\text { and training programmes are } \\
\text { effective for the knowledge } \\
\text { management practices of the } \\
\text { institution }\end{array}$ & 4.07 & 0.873 & 173 \\
\hline $\begin{array}{l}\text { Meeting of faculties from } \\
\text { different institutions is } \\
\text { desirable for knowledge } \\
\text { sharing and knowledge } \\
\text { management }\end{array}$ & 4.16 & 0.845 & 173 \\
\hline $\begin{array}{l}\text { There should be a dedicated } \\
\text { forum for knowledge sharing } \\
\text { among the faculty members } \\
\text { of various institutions }\end{array}$ & & & \\
\hline
\end{tabular}

Table 9 describes the descriptive statistics for faculty interaction and perception towards ICT. Majority of the respondents agreed that "Knowledge sharing is a strength to the organisation and to the country" as the statement has the highest mean score $(\mathrm{Mean}=4.32)$. The statement "Most of the faculties are adequately trained for ICT enabled knowledge management" got the lowest mean score $($ Mean=3.91) as most respondents did not agree to the statement.

\section{DISCUSSION}

Education is considered as the most important element for the successful living of life. The role of technical education is considered as a key of growth of India. India is considered as the largest pool of engineers who work in Multinational companies in large numbers for ensuring the growth of the country. The current study mainly focuses on the various kinds of knowledge management practices in the field of the technical educational institution and it also analyses the key areas especially in the technical education in a situation in which management of knowledge is the main focus. Furthermore, it also determines the various technical and knowledge management practices that provide strength to the human resources for ensuring the growth of the country (Thomas \&Parayil, 2008). While making the focus on the research mythologies which has been used by the researcher, it was found that descriptive research is used and questionnaire or interviews has been used in order to collect the relevant information based on the selected topic. The discussion and conclusion section describes the various key findings and results which has been collected by the researcher and also determine the future scope of the study in an effective manner.

In order to examine the various results from the collection based on the selected topic such as Knowledge 
Management Practices in Technical Educational Institutions using ICT tools with special refers to of Rayalaseema Region in Andhra Pradesh, the data has been collected on the basis of demographic section (Reddy, 2012). While making a focus on the data as per the gender, it was found that there were 173 respondents considered in the research study, in which $46.8 \%$ are male and $53.2 \%$ are female. Hence, it can be said that the majority of the participation level in favor of the female. Furthermore, to determine the age of the respondents, it was found that $97.7 \%$ of the participants were under the age group between 21-30 years old.

While examining the data based on the various branches of engineering courses offered by the institution, it was examined that there were $49.7 \%$ have computer science, $20.2 \%$ have electronic and telecommunication of branches of engineering course. It can be said that technical institutions are less as compare to computer science. Furthermore, to determine the primary source of teaching material defined that result that $56.5 \%$ of the institution highly prefers textbooks and there were only $35 \%$ who refer notes. To determine the internet and $\mathrm{Wi}-\mathrm{Fi}$ facilities provided by the institution, the data showed the result that $60.1 \%$ institution have the internet and $\mathrm{Wi}-\mathrm{Fi}$ facility for the students and there were $51.4 \%$ of the students who in favor of access the internet facility in the institution.

While making focus on knowledge management system, the data showed the results that there were $68.8 \%$ of the respondents who were in favour that institutions have their own active knowledge management system and $15 \%$ of the respondents who were in against the statement that some of them in situations have not their own knowledge management system (Rajasekaran, 1993). In addition to this, by analyzing the data gathered, it was found that educational institutions give emphasis to learning by any means. The institutions do not force standardised educational methods if the students are found to be learning through other mediums. The institutes follow certain approaches for implementation of knowledge management system. During the starting of each academic year, areas where knowledge management is required are identified. The institutions also place greater emphasis on acquisition and creation of knowledge related sources. However, most institutions do not have delegated workforce to overlook the process of knowledge management system or reserve the gathered knowledge. The interfaces of ICT enabled knowledge management tool is not convenient for most users and although training programs on knowledge management system are arranged for students and faculties, their applicability and reliability are not guaranteed. However, knowledge management system does help in learning process of both students and the faculties. Educational institutions conduct periodic seminars on various subjects and experts are invited to share their knowledge. These activities help all involving parties and also help in institution and industry collaboration. Hence, it can be said that knowledge management practices in Technical education institutions using ICFT tools make a great impact on the education level of the students (Rao, 2011).

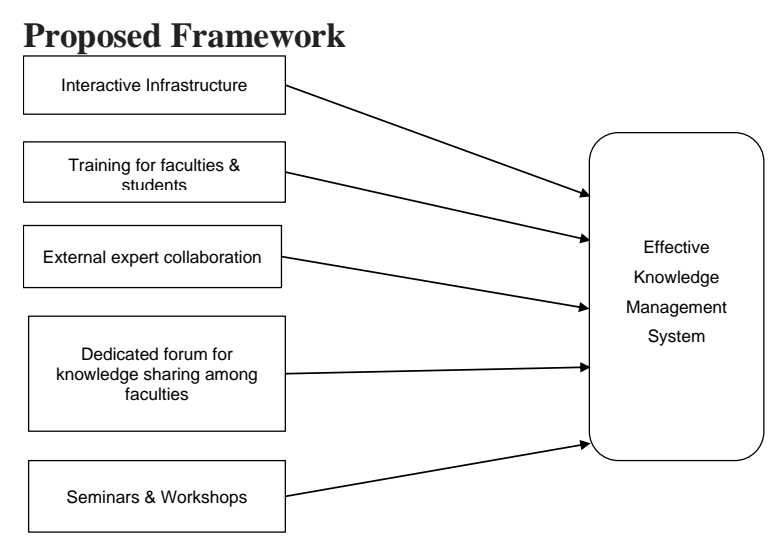

Figure 1: Proposed framework for effective Knowledge management system

From the gathered data and subsequent analysis certain factors are found to be important for effective implementation of knowledge management system. Interactive infrastructure is paramount for a knowledge management system where the students and faculties can communicate and share knowledge. Training programs are necessary to familiarise the students and faculties with the knowledge management platform. External expert collaboration brings outside and vast auxiliary knowledge to the institution that the internal providers may be lacking in. Apart from interactive infrastructure at least one dedicated forum should be commissioned by institutions where students and faculties can communicate with themselves and with external parties. Seminars and workshops are different from traditional classroom teaching methods. Here the students can learn from invited experts or even can share knowledge among themselves by focusing on any particular area through creative endeavours.

\section{CONCLUSION}

From the above detailed, it can be concluded that knowledge management in an institution of higher learning plays an important role which includes communication unity practices, learned lessons, formal training, social interaction that helps the students for ensuring the future growth in their life. Considering ICT for knowledge control in technical institutions in India, there's scarcity of research on the subject and relating Rayalaseema place, none exists. The relevance and importance of ICT for technical schooling in India is undeniable. However, in the absence of high-quality research, the state of ICT enabled understanding control practices and its related traits which include influences and barriers are unknown. These studies can bridge that gap and provide guidelines for improvement of ICT enabled understanding of management practices. Thus, it is less entail to build up an effective IT strategy knowledge management system in engineering colleges and apply the acquired knowledge wherever necessary. 


\section{KNOWLEDGE MANAGEMENT PRACTICES IN TECHNICAL EDUCATIONAL INSTITUTIONS USING ICT TOOLS OF RAYALASEEMA REGION IN ANDHRA PRADESH}

\section{RECOMMENDATIONS}

In ordered to provide knowledge management system in institution especially in the field of IT, there are some recommendations which are as follows:

- It is essential for the technical and engineering college's especially Rayalaseema region in Andhra Pradesh, to adopt the right use of ICT tools for better knowledge management.

- In order to access assess the knowledge management practices followed by technical educational institutions in Rayalaseema region of Andhra Pradesh; it also requires adopting right practices such as community practices, and formal training. Rsearch

- It is also essential to assess the shortcomings of present ICT enabled knowledge management practices of technical educational institutions in Rayalaseema region of Andhra Pradesh.

- Increased use of technologies in the form of enotes, learning apps, etc. also help for further improvement of ICT enabled knowledge management practices.

\section{REFERENCES}

1. Agrawal, D., Role Of ICT In Rural Development of India. EPRA International Journal of Economic and Business Review, e-ISSN, pp.2347-9671.

2. Gangaiah, B. and Viswanath, J., 2014. Impact of Indian management education in developing entrepreneurial aspirations and attitudes among management students.Asia Pacific Journal of Research, 1.

3. Gyaase, P.O., Anane, E.T. and Armah, I.N.A., 2015. The Use of Information and Communication Technology (ICT) for Knowledge Management in the Second Cycle Educational Institutions in Ghana.International Journal of Computer Applications, 128(7).

4. Kumar, K., 2013. Knowledge on ICT skills among LIS professionals of engineering institutions of Andhra Pradesh State: a survey. DESIDOC Journal of Library \& Information Technology, 33(6).

5. Kumar, K., 2014. Digital Collection and Development Initiatives in Engineering College Libraries: An Analytical Survey. INTERNATIONAL JOURNAL OF KNOWLEDGE CONTENT DEVELOPMENT and TECHNOLOGY, 4(1), pp.5-21.

6. Kumari, P.L. and Reddy, K.G., 2013.Knowledge and practices of safety use of pesticides among farm workers.J AgrVeterSci, 6(2), pp.1-8.

7. Laal, M., 2011.Knowledge management in higher education.Procedia Computer Science, 3, pp.544-549.

8. Madhar, M.A., 2010. Knowledge management in higher educational institutions with special reference to College of Applied Sciences (CAS), Ministry of Higher Education, Sultanate of Oman.

9. Maryam, M., 2013.Feasibility and application of ICT in secondary schools.

10. MUKUNDA RAO, B.O.R.R.A., 2011. AN ANALYTICAL STUDY ON Bt. COTTON CULTIVATION IN ANDHRA PRADESH (Doctoral dissertation, ACHARYA NG RANGA AGRICULTURAL UNIVERSITY).

11. Nawaz, M.N. and Gomes, A.M., 2014. Review of knowledge management in higher education institutions. European journal of business and management, 6(7), pp.71-79.

12. Pinto, M., 2014. Knowledge management in higher education institutions: a framework to improve collaboration. Information System and Technologies (CISTI).

13. Reddy, V.R., 2012. Hydrological externalities and livelihoods impacts: Informed communities for better resource management. Journal of Hydrology, 412, pp.279290.

14. Sarkar, S., 2012.The role of information and communication technology (ICT) in higher education for the 21st century.Science, l(1), pp.30-41.

15. Thomas, J.J. and Parayil, G., 2008. Bridging the social and digital divides in Andhra Pradesh and Kerala: A capabilities approach.Development and Change, 39(3), pp.409-435. 